\title{
The effects of wastewater reuse on potato growth properties under greenhouse lysimeteric condition
}

\author{
S. Marofi • N. Parsafar • G. H. Rahim • \\ F. Dashti $\cdot$ H. Marofi
}

Received: 10 June 2011/Revised: 22 November 2011/ Accepted: 9 June 2012/Published online: 21 September 2012

(c) CEERS, IAU 2012

\begin{abstract}
In this study, raw and treated wastewaters were reused for potato cultivation in order to verify the effect of wastewater on crop yield, crop's heavy metals' concentration as well as some major traits of potato. To this regard, a completely randomized test was designed with five water treatments and three replications. The watering were as follows: raw wastewater $\left(\mathrm{T}_{1}\right)$, treated wastewater $\left(\mathrm{T}_{2}\right)$, a combination of $50 \%$ raw wastewater and $50 \%$ fresh water $\left(\mathrm{T}_{3}\right)$, a combination of $50 \%$ treated wastewater and $50 \%$ fresh water $\left(\mathrm{T}_{4}\right)$, and fresh water $\left(\mathrm{T}_{5}\right)$. The experiments were run during October 2009-June 2010 in the greenhouse of Bu-Ali Sina University. The results show that the effects of treatments were significant on the length and number of stems per plant $(p<0.05)$. The number of nodes and weight of tubers, crop yield and heavy metal (cadmium, nickel and lead) concentration in shoots and tubers were also significant $(p<0.01)$. The results indicated that the highest length of stem $(55.44 \mathrm{~cm})$ was obtained in $\mathrm{T}_{2}$ which had no significant differences from that of $\mathrm{T}_{1}$. The maximum and minimum tuber weights and crop yield were obtained in $\mathrm{T}_{1}$ and $\mathrm{T}_{5}$, respectively. Based on crop yield rate, the watering ranked as follows:
\end{abstract}

S. Marofi $(\bowtie) \cdot$ N. Parsafar $\cdot$ H. Marofi

Department of Irrigation and Drainage Engineering, Faculty of Agriculture, Bu-Ali Sina University, Azadeghan Boulevard, 6517833131 Hamedan, Islamic Republic of Iran

e-mail: smarofi@yahoo.com; marofi@basu.ac.ir

\section{G. H. Rahim}

Department of Soil Science, Faculty of Agriculture, Bu-Ali Sina University, Hamedan, Islamic Republic of Iran

\section{F. Dashti}

Department of Horticulture, Faculty of Agriculture,

Bu-Ali Sina University, Hamedan, Islamic Republic of Iran
$\mathrm{T}_{1}>\mathrm{T}_{3}>\mathrm{T}_{2}>\mathrm{T}_{4}>\mathrm{T}_{5}$. The maximum and minimum heavy metal values were observed in $\mathrm{T}_{1}$ and $\mathrm{T}_{5}$, respectively. Based on the cadmium, nickel and lead accumulations in shoots and tubers (except cadmium in shoots), the watering treatments ranked as: $\mathrm{T}_{1}>\mathrm{T}_{3}>\mathrm{T}_{2}>\mathrm{T}_{4}>\mathrm{T}_{5}$.

Keywords Lysimetric cultivation - Heavy metal · Potato yield . Wastewaters reuse

\section{Introduction}

Wastewater reclamation and reuse have become an important element in water resource planning in arid and semi-arid regions (Abedi-Koupai and Bakhtiarifar 2003). In these regions of the world, water is increasingly becoming a scarce resource and planners are being forced to consider other water sources that could be used economically and effectively to promote further development (Pescod 1992).

Water supply and water quality degradation are global concerns that will intensify with increasing water demand, the unexpected impacts of extreme events, and climate change; for these reasons, marginal-quality water will become an increasingly important component of agricultural water supplies worldwide, particularly in water-scarce countries (Qadir et al. 2007). One of the major types of marginal-quality water is the wastewater from urban and peri-urban areas. Wastewater has been recycled in agriculture for centuries in cities such as Berlin, London, Milan, and Paris (AATSE 2004). Treated effluent can be used for irrigation under controlled conditions that minimize health risks from pathogenic and toxic pollution to agricultural products, soils, surface water, and groundwater (Mahasneh et al. 1989). Moreover, treated wastewater is a 
good source of water to control problems such as wastewater disposition and lack of water in arid zones. In addition, it can improve soil quality for crop production (Jiménez-Cisneros 1995).

In recent years, wastewater has gained importance in water-scarce regions. In Pakistan, $26 \%$ of national vegetable production is irrigated with wastewater (Ensink et al. 2004). In Ghana, informal irrigation involving diluted wastewater from rivers and streams occurs on an estimated 11,500 ha, an area larger than the reported extent of formal irrigation in the country (Keraita and Drechsel 2004). In Mexico, about 260,000 ha are irrigated with mostly untreated wastewater (Mexico CAN 2004). In most of these cases, the farmers irrigate with diluted, untreated, or partly treated wastewater. The failure to properly treat and manage wastewater generates adverse health effects. Farmers and their families using untreated wastewater are exposed to health risks from parasitic worms, viruses, and bacteria.

The effects of industrial and municipal wastewater on agricultural soils have been widely documented, mostly with regard to heavy metal concentrations and toxicology (Dominguez-Mariana et al. 2004; Yang 2002). However, the environmental impact of irrigation with treated wastewater has not been widely investigated. The need for direct and deliberate reuse of reclaimed sewage effluent is increasing. Its application for farming has been practiced in one form or another in many parts of the world for many generations (WHO 1980; Middlebrooks 1982). In particular, the use of untreated wastewater may result in a reduction of crop yield and deterioration in crop quality, while sodic water may adversely affect the physical properties of the soil that may consequently lead to reduction in crop yield. Considerable attention is presently being given to various aspects of water application, including the possibility of dispersing or creating even minute quantities of potentially harmful agents in the environment. Particularly, the effects of water on soils, crops, and water management are of increased concern to people when irrigating with wastewater, which may contain agents capable of inducing adverse effects on the soil media and on agricultural products (Lu et al. 2005).

The many benefits of irrigation with treated wastewater do come with certain risks to both humans and the environment. To manage these risks, the World Health Organization (WHO) offers guidelines for implementing safe wastewater reuse in agriculture that include treatment and non-treatment options from cultivation to consumption (WHO 2006). Very serious risks include crop yields reduction, crop quality deterioration, crop contamination with pathogens, and intestinal helminthes. It is however, possible to achieve high crop yields without the deterioration of quality using treated wastewater for the irrigation of crops under controlled conditions (Zavadil 2009).
Several studies have been conducted to investigate on the effects of municipal and industrial wastewater on soil and plants. Vafabakhsh and Kharghany (2000) studied the effects of treated municipal wastewater on quality and yield of cucumber and carrot. They concluded that the macro and micronutrients in stem, leaf, and the tuber of crop increased in the treatments which irrigated with treated wastewater compared to those irrigated with potable water.

Singh and Bahati (2005) showed that the use of municipal effluent had a positive influence on the growth and production of Dalbergia sissoo seedlings. The study suggests the potential use of municipal effluent for growing tree seedlings in the nutrient poor soil of dry areas in suburban area. Results obtained by Rezvani Moghadam and Mirzaei Najmabad (2009) showed the different sewage/water ratios of treatments resulted to significant differences on the height of plants, diameter of stems, number of tillers per plant, and dry matter yield of four forage species at $1 \%$ probability level. By increasing the sewage/ water ratio to $75 \%$ the height of plants increased; and at a $100 \%$ increase, the diameter of the stem and the dry matter yield increased. Aiello et al. (2007) also showed that the wastewater application resulted in increased microbial contamination on the soil surface. A disturbed layer of soil was observed that was characterized by reduced soil porosity and a consequent decrease in water retention and hydraulic conductivity. The negligible microbial contamination of fruit wash and washing solution suggested that treated wastewater could be used as a valid alternative for the irrigation of tomatoes.

Kiziloglu et al. (2008) showed that the highest yield of cauliflower and red cabbage plants was obtained with untreated wastewater. Undesirable side effects such as heavy metal contamination of soil and plant, and salinity were not observed with the application of wastewater. It can be concluded that untreated wastewater can be used confidently in the short-term in agricultural lands, while primary treated wastewater can be used for sustainable agriculture in the long-term.

In Iran, the volume of non-prime water resources such as industrial and municipal effluent waters was about $3.36 \times 10^{9} \mathrm{~m}^{3}$ in 1996 , of which $2.5 \times 10^{9} \mathrm{~m}^{3}$ are from municipal sewage (Statistical Handbook 1996). Based on the recent literature, it is necessary to set a plan to study the long-term and short-term effects of wastewater application on the environment, such as the effects on the following: food chain, different plant parts, and agricultural resources pollution. Therefore, in this study, the effects of different wastewaters on crop's heavy metal accumulation, crop yield, as well as on some major quantity and quality traits of potato (a major Hamedan region agricultural product) were investigated in cultivation using an especial volumetric lysimeter. 
This study was conducted in an experimental greenhouse located in Hamedan $\left(48^{\circ} 31^{\prime} \mathrm{E}\right.$ and $\left.34^{\circ} 48^{\prime} \mathrm{N}\right)$, a western city of Iran. Raw and treated-wastewater conveyed from the Serkan Wastewater Treatment Plant $\left(48^{\circ} 27^{\prime} \mathrm{E}\right.$ and $34^{\circ} 36^{\prime} \mathrm{N}$ ), placed at $70 \mathrm{~km}$ east of Hamedan, in other to reuse for potato (Morfona variety) cultivation during March 2010-June 2010. The experiment was run for a period of 9 months (October 2009-June 2010), including 5 months for soil preparation (in lysimeters) and 4 months for crop cultivation and harvesting.

\section{Materials and methods}

A completely randomized experiment of five watering treatments and three replicates were designed. The irrigation treated watering were as follows: raw wastewater $\left(\mathrm{T}_{1}\right)$, treated wastewater $\left(\mathrm{T}_{2}\right)$, a combination of $50 \%$ raw wastewater and $50 \%$ fresh water $\left(\mathrm{T}_{3}\right)$, a combination of $50 \%$ treated wastewater and $50 \%$ fresh water $\left(\mathrm{T}_{4}\right)$, and fresh water $\left(\mathrm{T}_{5}\right)$.

Fifteen volumetric lysimeters (254 l) were constructed from isolated steel cylinders $(60 \mathrm{~cm}$ diameter $\times 90 \mathrm{~cm}$ height), in which there were two separate containers: the upper part $(80 \mathrm{~cm})$ was filled with soil and the lower part $(10 \mathrm{~cm})$ was placed on the floor of the lysimeter. The lower container was designed for leaching water (considered as drainage water) accumulation. A fin filtering system was designed on the floor of upper container of the lysimeters (Fig. 1).

The soil had two layers: sandy loam $(0-30 \mathrm{~cm}$ in depth) and sandy clay loam (30-70 cm in depth). In Table 1, the soil properties are provided. Soil texture was determined by using the hydrometric method. The lysimeter soil characteristics (such as type of soil layers and their thicknesses) designed based on the global natural soil situation of the

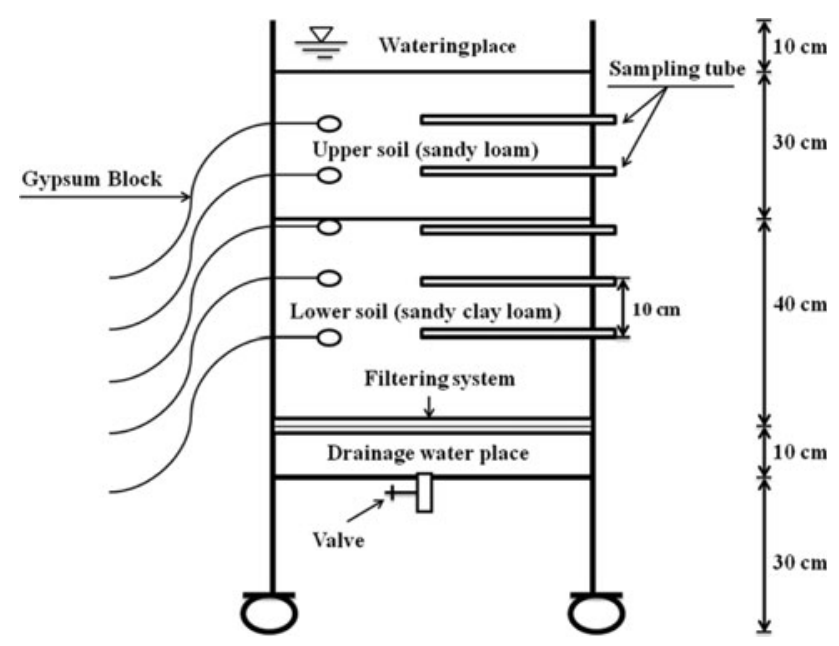

Fig. 1 Schematic and dimensions of the used lysimeter
Table 1 Properties of the used soils

\begin{tabular}{lllll}
\hline Texture & Clay $(\%)$ & Silt $(\%)$ & Sand $(\%)$ & Soil depth $(\mathrm{cm})$ \\
\hline Sandy loam & 18.97 & 20.26 & 60.77 & 30 \\
Sandy clay loam & 25.52 & 21.92 & 52.56 & 40 \\
\hline
\end{tabular}

region. The soil was sieved through a $1 \mathrm{~cm}$ mesh and coarse particles; weeds were also removed to obtain a uniform soil. In order to reach the natural condition of soil (with developed preferential and breakthrough flows), the lysimeters were irrigated systematically each week (during a period of 5 months) before sowing operations. Overall, eight irrigation programs with 11-day intervals were applied.

Four tubers of the potato cultivar Marfona were sown (10 cm deep) in each lysimeter on March 1, 2010. The plants were harvested on June 22, after approximately 4 months of growth. In order to have an easy condition for the eyes of the tubers to become to sprout, fresh water was used in the first irrigation program of all lysimeters. Watering treatments were used for the succeeding irrigations. With regard to the soil moisture, air and plant conditions, the volume of the irrigation water was varied between 30 and 351 .

\section{Measurements}

In order to measure copper $(\mathrm{Cu})$, zinc $(\mathrm{Zn})$, iron $(\mathrm{Fe})$, cadmium $(\mathrm{Cd})$, nickel $(\mathrm{Ni})$, lead $(\mathrm{Pb})$, and manganese $(\mathrm{Mn})$ concentrations in the input (irrigated) water treatments $\left(\mathrm{T}_{1}-\right.$ $\mathrm{T}_{5}$ ), 21 samples of the raw-wastewater, treated-wastewater and fresh water were systematically collected and analyzed during the second to eighth irrigation programs. The samples were stored in $250 \mathrm{cc}$ Shcott glass bottles. They were filtered through Whatman $42 \mathrm{~mm}$ filter papers, and stored at $4{ }^{\circ} \mathrm{C}$ (OMA 1990) within $48 \mathrm{~h}$. Before sampling, the bottles were washed with a $10 \%$ solution of reagent grade nitric acid and deionized water, hot tap (fresh) water, rinsed with distilled water, and dried at the air temperature of laboratory. The concentrations of the heavy metals were measured using a flame atomic absorption spectrophotometer (AAS Varian Model 220). Because of the existence of floating particles in the raw and the treated wastewaters, the samples were digested by Aqua Regia $\left(\mathrm{HNO}_{3}: \mathrm{HCl}\right.$ in $1: 3$ ratio) before heavy metal analysis.

Tests on electrical conductivity (EC), $\mathrm{pH}$, chemical oxygen demand (COD), biochemical oxygen demand $\left(\mathrm{BOD}_{5}\right)$, and suspended solids (SS) were carried out according to generally accepted basic laboratory procedures of the American Public Health Association Standard Methods for the Examination of Water and Wastewater (Standard Methods 1995).

At the end of the growing period, tubers and shoots of the plants were harvested. To remove airborne pollutants, 
all the collected samples were washed carefully with clear water (fresh), and then rinsed with distilled water. They were dried in a hot air oven at $70-80{ }^{\circ} \mathrm{C}$ for $72 \mathrm{~h}$, in order to reduce water content. Before harvesting, the number of stems and their lengths and nodes per plant were measured. After harvesting, crop yield, weight and number of tubers per plant, shoots and tuber dry matter (in percentage), and total tuber dry matter were measured. The dry matter of the tubers and shoots was recorded after oven drying (at $70-80{ }^{\circ} \mathrm{C}$ during $72 \mathrm{~h}$ ). The percentages of the tuber diameter were sorted on three categories: smaller than 35 $\left(\mathrm{C}_{1}\right), 35-55\left(\mathrm{C}_{2}\right)$ and more than $55 \mathrm{~mm}\left(\mathrm{C}_{3}\right)$.

Digestion of the plant samples

Thirty samples of plants (15 tubers and 15 shoots) were analyzed for each heavy metal $(\mathrm{Ni}, \mathrm{Pb}$, and $\mathrm{Cd})$ measurement. To prepare the plant digestion; first, a weight equal to $1 \mathrm{~g}$ of each sample was placed in crucibles. Then, the samples were ashed in furnace at $500{ }^{\circ} \mathrm{C}$ and digested by chloride acid (20\%). Finally, they were filtered through a Whatman (no. 42). $\mathrm{Ni}, \mathrm{Pb}$, and $\mathrm{Cd}$ concentrations in the plant extracts were determined by atomic absorption spectrophotometer (AAS Varian Model 220).

\section{Standard solutions}

Standard solutions of heavy metals $(1,000 \mathrm{mg} / \mathrm{L})$, including $\mathrm{Ni}, \mathrm{Pb}$, and $\mathrm{Cd}$ were provided. Solutions of varying concentrations were prepared for all the metals by diluting the standards.

\section{Statistical analysis}

Statistical parameters of heavy metals concentrations of the samples (harvested potato shoots and tubers), crop yield, and some quantity and quality traits of the potato were calculated from $T_{1}$ to $T_{5}$ to present the variations within these plant characteristics during the treatments. Duncan's multiple range tests was used to compare the average values among the water treatments. The statistical significance was at a probability ( $p)$ level of $p<0.05$. All the data were analyzed using the SAS 9.1 statistical package and Excel software.

\section{Results and discussion}

Quality of the used waters (fresh, raw and treated wastewater)

The heavy metal concentrations $(\mathrm{Cu}, \mathrm{Zn}, \mathrm{Fe}, \mathrm{Cd}, \mathrm{Ni}, \mathrm{Pb}$ and $\mathrm{Mn}$ ), $\mathrm{BOD}_{5}, \mathrm{COD}$, and $\mathrm{SS}$ of the fresh and raw waters as well as treated-wastewater are shown in Table 2. Based
Table 2 The average heavy metals concentrations, $\mathrm{BOD}_{5}, \mathrm{COD}$ and $\mathrm{SS}$ in $\mathrm{T}_{1}, \mathrm{~T}_{2}$ and $\mathrm{T}_{5}$

\begin{tabular}{|c|c|c|c|c|c|}
\hline \multirow[t]{2}{*}{ Elements } & \multicolumn{3}{|c|}{ Water treatments } & \multicolumn{2}{|c|}{ Standards $^{\mathrm{a}}$} \\
\hline & $\mathrm{T}_{1}$ & $\mathrm{~T}_{2}$ & $\mathrm{~T}_{5}$ & IEPO & FAO \\
\hline $\mathrm{Cd}(\mathrm{mg} / \mathrm{L})$ & 0.014 & 0.010 & 0.006 & 0.01 & 0.01 \\
\hline $\mathrm{Ni}(\mathrm{mg} / \mathrm{L})$ & 0.060 & 0.034 & 0.027 & 0.20 & 0.20 \\
\hline $\mathrm{Cu}(\mathrm{mg} / \mathrm{L})$ & 0.070 & 0.052 & 0.031 & 0.20 & 0.20 \\
\hline Mn (mg/L) & 0.056 & 0.028 & 0.005 & 0.20 & 0.20 \\
\hline $\mathrm{Fe}(\mathrm{mg} / \mathrm{L})$ & 0.604 & 0.262 & 0.040 & 5 & 5 \\
\hline $\mathrm{Zn}(\mathrm{mg} / \mathrm{L})$ & 0.615 & 0.375 & 0.110 & 2 & 2 \\
\hline $\mathrm{Pb}(\mathrm{mg} / \mathrm{L})$ & 0.064 & 0.034 & 0.013 & 1 & 5 \\
\hline $\mathrm{BOD}_{5}(\mathrm{mg} / \mathrm{L})$ & 187.75 & 13.90 & - & 100 & - \\
\hline COD (mg/L) & 341.75 & 24.61 & - & 200 & - \\
\hline $\mathrm{SS}(\mathrm{mg} / \mathrm{L})$ & 0.810 & 0 & - & 0.10 & - \\
\hline $\mathrm{EC}\left(\mathrm{dsm}^{-1}\right)$ & 0.765 & 0.619 & 0.739 & & $<3$ \\
\hline $\mathrm{pH}$ & 7.070 & 7.290 & 7.670 & & $6.5-8.4$ \\
\hline
\end{tabular}

${ }^{\mathrm{a}}$ FAO (based on Pescod ${ }^{2}$ ) and IEPO

on the FAO (Pescod 1992) and the standard of the Iranian environmental protection organization (IEPO), the heavy metal concentrations of the raw and treated-wastewaters are within acceptable range (except for cadmium level in the raw wastewater). As compared to raw wastewater, the mean of heavy metals in the treated-wastewater was lower. Also, based on the IEPO standard, $\mathrm{pH}$ and EC of the water treatments were within acceptable range. The mean values of $\mathrm{BOD}_{5}, \mathrm{COD}$, and $\mathrm{SS}$ of $\mathrm{T}_{2}$ and $\mathrm{T}_{5}$ were within acceptable range, but the mean of $\mathrm{BOD}_{5}$ and COD of $\mathrm{T}_{1}$ were more than the values of IEPO standard. In the case of $T_{3}$ and $\mathrm{T}_{4}$, these parameters were not analyzed.

\section{Potato traits}

The results showed effects of the water treatments were significant on the stem length, number of stem per plant $(p<0.05)$, number of nodes, weight of tubers per plant, total amount of dry matter of tubers, and crop yield $(p<0.01)$. Also, effects of the treatments were not significant on the number of tubers per plant, percentage of shoots, and total amount of dry matter of tubers (Table 3).

\section{Length of stem}

The raw and treated watering proved wastewater effects on the some potato growth properties during a period of 4 months. This result indicated the mean highest length of stems $(55.44 \mathrm{~cm})$ obtained in $\mathrm{T}_{2}$ that was similar to the result of $T_{1}$. Also, the mean lowest length of stems $(37.28 \mathrm{~cm})$ was in $T_{5}$, which was not significantly different when compared to that of $T_{1}, T_{3}$ and $T_{4}(p>0.05)$. 
Table 3 Statistical analysis of the potato traits

\begin{tabular}{|c|c|c|}
\hline Traits & SS & MS \\
\hline Length of stem $(\mathrm{cm})$ & 680.32 & $170.08 *$ \\
\hline Number of nodes per plant & 721.77 & $180.44 * *$ \\
\hline Number of stems per plant & 2.02 & $0.51 *$ \\
\hline Number of tubers per plant & 25.50 & $6.37^{\mathrm{ns}}$ \\
\hline Weight of tubers per plant $(\mathrm{kg})$ & 0.12 & $0.03 * *$ \\
\hline Dry matter of shoots (\%) & 293.40 & $73.35^{\mathrm{ns}}$ \\
\hline Dry matter of tubers (\%) & 1.74 & $0.44^{\mathrm{ns}}$ \\
\hline Total dry mater of tubers $(\mathrm{kg})$ & 0.06 & $0.014 * *$ \\
\hline Crop yield $\left(\mathrm{kg} \mathrm{m}^{-2}\right)$ & 24.16 & $6.04 * *$ \\
\hline Tubers of group $\mathrm{C}_{1}(\%)$ & 521.01 & $130.25^{\mathrm{ns}}$ \\
\hline Tubers of group $\mathrm{C}_{2}(\%)$ & 382.93 & $95.73^{\mathrm{ns}}$ \\
\hline Tubers of group $\mathrm{C}_{3}(\%)$ & 188.23 & $47.06^{\text {ns }}$ \\
\hline
\end{tabular}

$S S$ sum of squares, $M S$ mean squares, $n s$ non-significant

** Significant at $1 \%$ level; $*$ Significant at $5 \%$ level

\section{Numbers of nodes and tubers}

The maximum number of nodes per plants (35.17) was obtained in $\mathrm{T}_{1}$, which was not significantly different $(p>0.05)$ with $\mathrm{T}_{3}$. The minimum number of nodes per plants (13.83) was observed in $\mathrm{T}_{5}$. Also, the maximum number of tubers per plants was observed in $T_{2}$, which was similar with that of $T_{1}, T_{3}$ and $T_{4}, T_{5}$ had the minimum number of tubers per plants, which was not significantly different from that of $\mathrm{T}_{1}, \mathrm{~T}_{3}$ and $\mathrm{T}_{4}$ (Table 4).

\section{Number of stems}

The maximum number of stems per plants (3) was observed in $\mathrm{T}_{1}, \mathrm{~T}_{2}, \mathrm{~T}_{3}$ and $\mathrm{T}_{4}, \mathrm{~T}_{5}$ had the minimum number of stems (2, Table 4).

\section{Tubers' weight per plant, total dry matter of tubers and crop yield}

The maximum tubers' weight per plant $(0.683 \mathrm{~kg})$, total amount of dry matter of tubers $(0.483 \mathrm{~kg})$, and crop yield $\left(9.67 \mathrm{~kg} \mathrm{~m}^{-2}\right)$ were obtained in $\mathrm{T}_{1}$. The minimum values of these parameters were $0.407,0.293 \mathrm{~kg}$, and $5.77 \mathrm{~kg} \mathrm{~m}^{-2}$ observed in $\mathrm{T}_{5}$. There were no significant differences $(p>0.05)$ between $\mathrm{T}_{2}, \mathrm{~T}_{3}$, and $\mathrm{T}_{4}$ (Tables 4,5$)$.

\section{Percentages of dry matter of shoots}

The maximum percentage of dry matter of shoots $(19.58 \%)$ was obtained in $\mathrm{T}_{1}$, which had no significant variations $(p>0.05)$ with $\mathrm{T}_{2}, \mathrm{~T}_{3}$, and $\mathrm{T}_{4}$. The minimum value $(7.17 \%)$ was obtained in $\mathrm{T}_{5}$, which was not significantly different from that of $\mathrm{T}_{2}, \mathrm{~T}_{3}$ and $\mathrm{T}_{4}$.

\section{Percentages of dry matter of tubers}

The maximum percentage of dry matter of tubers (18.6\%) was obtained in $\mathrm{T}_{4}$, which was not significantly different $(p>0.05)$ from that of other treatments. The minimum value $(17.67 \%)$ belonged to $\mathrm{T}_{1}$, which was not significantly different from that of other treatments. Overall, there were not significant differences among treatments in the case of the dry matter of tubers (Tables 4,5 ).

\section{Tubers range}

The result showed that water treatments had no significant effects on tuber growth, based on the three considered diameter classes $\left(C_{1}-C_{3}\right.$, Table 3$) . C_{3}$ in $T_{1}$ had the maximum percentage of tubers. There were no significant differences $(p>0.05)$ between treatments regarding tuber diameter (Table 5).

Heavy metal concentration in potato shoots

Statistical analysis of heavy metal concentrations in potato shoots is shown in Table 6. This result illustrated the effect of the water treatments on the shoots' accumulated heavy metals $(\mathrm{Pb}, \mathrm{Ni}$, and $\mathrm{Cd})$ was statistically significant $(p<0.01)$.

A comparison of the average values of heavy metals of the shoots is shown in Table 7. According to these results, maximum Cd concentration was obtained in $\mathrm{T}_{1}$, which had no significant differences $(p>0.05)$ from that of $T_{2}$ and $\mathrm{T}_{3}$. The minimum rate was also obtained in $\mathrm{T}_{5}$. The maximum and the minimum $\mathrm{Pb}$ and $\mathrm{Ni}$ values were obtained in
Table 4 Effect of water treatments on the potato traits

* At each column, values followed by different letters significantly differ between the treatments $(p<0.05)$

\begin{tabular}{llllllc}
\hline Treatments & \multicolumn{2}{l}{ Number of (per plant) } & & $\begin{array}{l}\text { Length of } \\
\text { stem }(\mathrm{cm})\end{array}$ & $\begin{array}{l}\text { Weight of tubers } \\
\text { per plant }(\mathrm{kg})\end{array}$ & $\begin{array}{l}\text { Dry matter in } \\
\text { shoots }(\%)\end{array}$ \\
\cline { 2 - 5 } & Nodes & Stems & Tubers & & & \\
\hline $\mathrm{T}_{1}$ & $35.17^{\mathrm{a}}$ & $3.00^{\mathrm{a}}$ & $9.75^{\mathrm{ab}}$ & $49.50^{\mathrm{ab} *}$ & $0.683^{\mathrm{a}}$ & $19.58^{\mathrm{a}}$ \\
$\mathrm{T}_{2}$ & $23.33^{\mathrm{b}}$ & $2.92^{\mathrm{a}}$ & $11.50^{\mathrm{a}}$ & $55.44^{\mathrm{a}}$ & $0.505^{\mathrm{b}}$ & $13.55^{\mathrm{ab}}$ \\
$\mathrm{T}_{3}$ & $28.58^{\mathrm{ab}}$ & $2.92^{\mathrm{a}}$ & $9.02^{\mathrm{ab}}$ & $42.85^{\mathrm{b}}$ & $0.520^{\mathrm{b}}$ & $9.88^{\mathrm{ab}}$ \\
$\mathrm{T}_{4}$ & $24.50^{\mathrm{b}}$ & $2.75^{\mathrm{a}}$ & $9.75^{\mathrm{ab}}$ & $39.23^{\mathrm{b}}$ & $0.495^{\mathrm{b}}$ & $8.78^{\mathrm{ab}}$ \\
$\mathrm{T}_{5}$ & $13.83^{\mathrm{c}}$ & $2^{\mathrm{b}}$ & $7.417^{\mathrm{b}}$ & $37.28^{\mathrm{b}}$ & $0.407^{\mathrm{c}}$ & $7.17^{\mathrm{b}}$ \\
\hline
\end{tabular}


Table 5 Effect of water treatments on crop yield, dry matter and percentage of tuber diameters

* At each column, values followed by different letters significantly differ between the treatments $(p<0.05)$

\begin{tabular}{llllllr}
\hline Treatments & $\begin{array}{l}\text { Crop yield } \\
\left(\mathrm{kg} \mathrm{m}^{-2}\right)\end{array}$ & $\begin{array}{l}\text { Dry matter } \\
\text { in tuber }(\%)\end{array}$ & $\begin{array}{l}\text { Total dry matter } \\
\text { of tuber }(\mathrm{kg})\end{array}$ & \multicolumn{3}{l}{ Tubers groups $(\%)$} \\
\cline { 5 - 7 } & & & & $\mathrm{C}_{1}$ & \multicolumn{1}{c}{$\mathrm{C}_{2}$} & \multicolumn{1}{c}{$\mathrm{C}_{3}$} \\
\hline $\mathrm{T}_{1}$ & $9.67^{\mathrm{a} *}$ & $17.67^{\mathrm{a}}$ & $0.48^{\mathrm{a}}$ & $31.48^{\mathrm{a}}$ & $54.31^{\mathrm{a}}$ & $14.21^{\mathrm{a}}$ \\
$\mathrm{T}_{2}$ & $7.15^{\mathrm{b}}$ & $18.40^{\mathrm{a}}$ & $0.37^{\mathrm{b}}$ & $45.29^{\mathrm{a}}$ & $49.60^{\mathrm{a}}$ & $5.11^{\mathrm{a}}$ \\
$\mathrm{T}_{3}$ & $7.35^{\mathrm{b}}$ & $17.88^{\mathrm{a}}$ & $0.37^{\mathrm{b}}$ & $46.04^{\mathrm{a}}$ & $43.12^{\mathrm{a}}$ & $10.84^{\mathrm{a}}$ \\
$\mathrm{T}_{4}$ & $7.01^{\mathrm{b}}$ & $18.60^{\mathrm{a}}$ & $0.37^{\mathrm{b}}$ & $38.22^{\mathrm{a}}$ & $56.71^{\mathrm{a}}$ & $5.07^{\mathrm{a}}$ \\
$\mathrm{T}_{5}$ & $5.77^{\mathrm{c}}$ & $18.01^{\mathrm{a}}$ & $0.29^{\mathrm{c}}$ & $46.75^{\mathrm{a}}$ & $45.92^{\mathrm{a}}$ & $7.33^{\mathrm{a}}$ \\
\hline
\end{tabular}

Table 6 Statistical analysis of the heavy metals concentrations $\left(\mathrm{mg} \mathrm{kg}^{-1}\right)$ in the shoots of potato

\begin{tabular}{lrr}
\hline Elements & \multicolumn{1}{c}{ SS } & \multicolumn{1}{c}{ MS } \\
\hline $\mathrm{Cd}$ & 0.90 & $0.23^{* *}$ \\
$\mathrm{Ni}$ & 11.75 & $2.94 * *$ \\
$\mathrm{~Pb}$ & 64.40 & $16.10^{* *}$ \\
\hline
\end{tabular}

$S S$ sum of squares, $M S$ mean squares

** Significant at $1 \%$ level

Table 7 Comparison of the average heavy metals concentrations $\left(\mathrm{mg} \mathrm{kg}^{-1}\right)$ in the shoots of potato of the watering treatments calculated by Duncan test

\begin{tabular}{llll}
\hline Treatments & $\mathrm{Cd}$ & $\mathrm{Ni}$ & $\mathrm{Pb}$ \\
\hline $\mathrm{T}_{1}$ & $1.72^{\mathrm{a} *}$ & $8.98^{\mathrm{a}}$ & $7^{\mathrm{a}}$ \\
$\mathrm{T}_{2}$ & $1.48^{\mathrm{ab}}$ & $7.87^{\mathrm{b}}$ & $4^{\mathrm{b}}$ \\
$\mathrm{T}_{3}$ & $1.42^{\mathrm{ab}}$ & $8.02^{\mathrm{b}}$ & $4.17^{\mathrm{b}}$ \\
$\mathrm{T}_{4}$ & $1.32^{\mathrm{b}}$ & $7.65^{\mathrm{b}}$ & $2.67^{\mathrm{b}}$ \\
$\mathrm{T}_{5}$ & $0.97^{\mathrm{c}}$ & $6.23^{\mathrm{c}}$ & $0.67^{\mathrm{c}}$ \\
\hline
\end{tabular}

* At each column, values followed by different letters significantly differ between the treatments $(p<0.05)$

$\mathrm{T}_{1}$ and $\mathrm{T}_{5}$, respectively. The result showed in all of the treatments (except $\mathrm{T}_{5}$ ), the amount of concentration of heavy metals was in the following order: $\mathrm{Ni}>\mathrm{Pb}>\mathrm{Cd}$. But in $\mathrm{T}_{5}$, the order was as follows: $\mathrm{Ni}>\mathrm{Cd}>\mathrm{Pb}$. The results also showed the maximum value of heavy metal was observed in $T_{1}$.

Overall, the results of this research showed that the amount of $\mathrm{Ni}$ and $\mathrm{Pb}$ accumulations in potato shoots of the various water treatments was in the following order: $\mathrm{T}_{1}>\mathrm{T}_{3}>\mathrm{T}_{2}>\mathrm{T}_{4}>\mathrm{T}_{5}$. In the case of the heavy metals, similar results were obtained in $\mathrm{T}_{2}, \mathrm{~T}_{3}$ and $\mathrm{T}_{4}$. Also, the results of this research showed that the amount of $\mathrm{Cd}$ accumulations in potato shoots of the various water treatments was in the following order: $T_{1}>T_{2}>T_{3}>$ $\mathrm{T}_{4}>\mathrm{T}_{5}$. In the case of $\mathrm{Cd}$, significant differences were identified between $T_{1}$ and $T_{4}$, as well as between $T_{5}$ and the other treatments.
Table 8 Statistical analysis of concentrations of heavy metals $\left(\mathrm{mg} \mathrm{kg}^{-1}\right)$ in tubers of potato

\begin{tabular}{lrl}
\hline Elements & \multicolumn{1}{c}{$\mathrm{SS}^{\mathrm{a}}$} & $\mathrm{MS}^{\mathrm{b}}$ \\
\hline $\mathrm{Cd}$ & 1.25 & $0.31^{* *}$ \\
$\mathrm{Ni}$ & 29.89 & $7.47^{* *}$ \\
$\mathrm{~Pb}$ & 5.99 & $1.50^{* *}$ \\
\hline
\end{tabular}

$S S$ sum of squares, $M S$ mean squares

** Significant at $1 \%$ level

Table 9 Comparison of the average heavy metals concentrations $\left(\mathrm{mg} \mathrm{kg}^{-1}\right)$ in tuber of potato of the water treatments calculated by Duncan test

\begin{tabular}{llll}
\hline Treatments & $\mathrm{Cd}$ & $\mathrm{Ni}$ & $\mathrm{Pb}$ \\
\hline $\mathrm{T}_{1}$ & $2.13^{\mathrm{a} *}$ & $6.98^{\mathrm{a}}$ & $1.88^{\mathrm{a}}$ \\
$\mathrm{T}_{2}$ & $1.58^{\mathrm{b}}$ & $4.42^{\mathrm{bc}}$ & $1.18^{\mathrm{b}}$ \\
$\mathrm{T}_{3}$ & $1.68^{\mathrm{b}}$ & $5.52^{\mathrm{ab}}$ & $1.38^{\mathrm{b}}$ \\
$\mathrm{T}_{4}$ & $1.43^{\mathrm{bc}}$ & $4.28^{\mathrm{bc}}$ & $0.78^{\mathrm{c}}$ \\
$\mathrm{T}_{5}$ & $1.28^{\mathrm{c}}$ & $2.73^{\mathrm{c}}$ & $0^{\mathrm{d}}$ \\
\hline
\end{tabular}

* At each column, values followed by different letters significantly differ between treatments $(p<0.05)$

Concentration of heavy metals in the potato tubers

The statistical analysis of the heavy metals concentration in tubers is shown in Table 8. This result showed that the effect of the water treatments on tubers' accumulated heavy metals $(\mathrm{Pb}, \mathrm{Ni}$ and $\mathrm{Cd})$ was statistically significant $(p<0.01)$.

A comparison of the average heavy metals concentration values in potato tubers is shown in Table 9. According to these results, the maximum $\mathrm{Cd}$ concentration was obtained in $\mathrm{T}_{1}$. The minimum also belonged to $\mathrm{T}_{5}$, which had not significant difference $(p>0.05)$ from that of $T_{4}$. The maximum and minimum $\mathrm{Pb}$ values were also obtained in $\mathrm{T}_{1}$ and $\mathrm{T}_{5}$, respectively.

In the case of $\mathrm{Ni}$, the result showed that the maximum value was obtained in $\mathrm{T}_{1}$, which did not have a significant difference $(p>0.05)$ with $\mathrm{T}_{3}$. Also, the minimum Ni value 
Table 10 Standard of heavy metal concentrations $\left(\mathrm{mg} \mathrm{kg}^{-1}\right)$ in vegetables, based on Allaway (1990), Pendias and Pendias (1992)

\begin{tabular}{ll}
\hline Elements & Critical value \\
\hline $\mathrm{Ni}$ & $10-100$ \\
$\mathrm{Cd}$ & $5-30$ \\
$\mathrm{~Pb}$ & $30-300$ \\
\hline
\end{tabular}

belonging to $\mathrm{T}_{5}$, which had not significant differences $(p>0.05)$ from that of $\mathrm{T}_{4}$ and $\mathrm{T}_{2}$.

The results showed in all of the treatments, the amount of heavy metal concentrations in the various water treatments were in the following order: $\mathrm{Ni}>\mathrm{Cd}>\mathrm{Pb}$. The results also showed that the maximum value of heavy metal concentrations was observed in $\mathrm{T}_{1}$. Overall, the results of this research showed that $\mathrm{Cd}, \mathrm{Ni}$, and $\mathrm{Pb}$ accumulations in potato tubers of the water treatments were in the following order: $\mathrm{T}_{1}>\mathrm{T}_{3}>\mathrm{T}_{2}>\mathrm{T}_{4}>\mathrm{T}_{5}$. As shown in Tables 7, 9, and 10 , the heavy metal concentrations in potato shoots and tubers were less than standard concentrations (within acceptable range).

In this study, the concentrations of three heavy metals $(\mathrm{Cd}$, $\mathrm{Ni}$, and $\mathrm{Pb}$ ), crop yield, and some major quantity and quality traits of potatoes were examined by using wastewaters as part of the watering programs on a greenhouse cultivation using lysimeters. In this regard, a completely randomized experiment consisted of five water treatments and three replicates $\left(T_{1}, T_{2}, T_{3}, T_{4}\right.$ and $\left.T_{5}\right)$ were designed and in totality eight irrigation programs were used. Potato shoots and tubers were sampled in order to analyze heavy metal concentrations in plant. Based on FAO (Pescod 1992) and IEPO standards, all the observed heavy metals were within acceptable ranges (except for Cd). According to the results, the effects of treatments were significant on the number of stems and their length per plant $(p<0.05$ at $5 \%$ level). The number of nodes, weight of tubers (per plant), crop yield, and heavy metal concentrations $(\mathrm{Cd}, \mathrm{Ni}$, and $\mathrm{Pb})$ were also significant in potato shoots and tubers $(p<0.01$ at $1 \%$ level).

The maximum numbers of stems, nodes, weight of tubers per plant, as well as crop yield were obtained in $T_{1}$. The minimum value of the considered parameters belonged to $\mathrm{T}_{5}$. In addition, in this study, the longest stem length and maximum number of tubers per plant were observed in $T_{2}$. Aiello et al. (2007) also showed that tomato yield increased by irrigation with wastewater. Kiziloglu et al. (2008) found that the yield of cauliflower and red cabbage plants increased by irrigation with wastewater.

Potato yield, depending on the various watering treatments, were in the following order: $T_{1}>T_{3}>T_{2}>$ $\mathrm{T}_{4}>\mathrm{T}_{5}$. Kiziloglu et al. (2008) stated that the yield of cauliflower and red cabbage plants was less in all soils irrigated with treated-wastewater than with untreated- wastewater. Also, Rezvani Moghadam and Mirzaei Najmabad 2009 showed that significant differences existed depending on the different sewage/water ratio treatments on height of plants, diameter of stems, number of tillers per plant, and dry matter yield of four forage species (at $1 \%$ probability level). They reported that by increasing the different sewage/water ratios to $75 \%$, the height of plants increased; and at $100 \%$ increase, the diameter of the stem and dry matter yield increased. Behbahaninia et al. (2009) showed that the concentration of heavy metals increased significantly in the soil and plants of plots irrigated with treated-wastewater compared with the control plot.

According to the results of this study, the maximum $\mathrm{Cd}$, $\mathrm{Ni}$, and $\mathrm{Pb}$ values were obtained in $\mathrm{T}_{1}$ and the minimum belonged to $T_{5}$. The difference between these plots $\left(T_{1}\right.$ and $\mathrm{T}_{5}$ ) was significant. Kiziloglu et al. (2008) showed that wastewater irrigation treatments increased $\mathrm{Pb}, \mathrm{Ni}$, and $\mathrm{Cd}$ contents of cauliflower and red cabbage plants. Behbahaninia et al. (2009) stated that the irrigation of agricultural lands by effluent and sewage sludge for several years increased heavy metals in soils and plants. Mohammad Rusan et al. (2007) reported that plant $\mathrm{Pb}$ and $\mathrm{Cd}$ increased with wastewater. Vafabakhsh and Kharghany (2000) concluded that the macro and micronutrients in the carrot's stem, leaf, and tuber were increased in treatments irrigated with treated-wastewater compared to fresh water. Overall, the results of this research showed the $\mathrm{Cd}, \mathrm{Ni}$, and $\mathrm{Pb}$ accumulation in potato shoots and tubers of the various treatments was in the following order: $T_{1}>T_{3}>T_{2}>$ $\mathrm{T}_{4}>\mathrm{T}_{5}$ (except Cd in shoots). Al-Lahham et al. (2007) indicated that the accumulation of heavy metals varied according to cultivar, but in the case of the tomato, the accumulation of heavy metals was more pronounced by increasing the proportion of treated-wastewater in irrigation (the pattern of accumulation follows the following order: 1:0<1:1 $<1: 3<0: 1$, potable water to treated-wastewater).

\section{Conclusion}

In this study, the results showed that in potato cultivation, $\mathrm{Ni}$ and $\mathrm{Pb}$ concentrations in tubers were less than in shoots. But $\mathrm{Cd}$ concentration in tubers was more than in shoots. Zheljazkov and Nielsen (1996) found that the concentration of heavy metals in vegetables per unit dry matter generally follow the order: leaves $>$ fresh fruits $>$ seeds. Long-term irrigation of plants with wastewater and sludge increased heavy metal contents in the soil. Therefore, plants grown on polluted soil could absorb relatively high quantities of heavy metals (Behbahaninia et al. 2009).

These results also showed that $\mathrm{Ni}$ was greatly concentrated in the shoots and tubers of potato. The results of Behbahaninia et al. (2009) showed that Ni had the greatest 
accumulation whereas the highest concentration of $\mathrm{Ni}$ for spinach was observed in the plot watered with the Shoush plant (located in south of Iran) sewage sludge and effluent.

Heavy metal accumulation $(\mathrm{Cd}, \mathrm{Ni}$, and $\mathrm{Pb})$ in potato shoots and tubers of the lysimeters irrigated with treatedwastewater was less than from that of the lysimeters supplied with raw wastewater. These results are in agreement with the finding of Kiziloglu et al. (2008). However, in this study, the accumulation of heavy metals $(\mathrm{Cd}, \mathrm{Ni}$, and $\mathrm{Pb})$ in potato tubers and shoots was less than the standard limits, and wastewater use in short-term irrigation might be feasible, but a heavy metal monitoring program is necessary.

Acknowledgments Special thanks are due to Bu-Ali Sina University managers for their financial and laboratory supports. The authors are also grateful to the anonymous reviewers whose suggestions significantly contributed to improve the work.

\section{References}

AATSE (Australian Academy of Technological Sciences and Engineering). (2004). Water recycling in Australia. AATSE, Victoria, Australia

Abedi-Koupai J, Bakhtiarifar A (2003) Investigation of the effect of treated wastewater on hydraulic properties of emitters in trickle irrigation system. In: 20th Eur. Region. Conf., CD Int. Workshop, Irrigation technologies and method: Research, development and testing, Montpellier, France

Aiello R, Luigi Cirelli G, Consoli S (2007) Effects of reclaimed wastewater irrigation on soil and tomato fruits: a case study in Sicily (Italy). Agr Water Manage 93:65-72

Al-Lahham O, El Assi NM, Fayyad M (2007) Translocation of heavy metals to tomato (Solanum lycopersicom L.) fruit irrigated with treated wastewater. Sci Hortic-Amsterdam 113:250-254

Allaway BJ (1990) Heavy metals in soils. Blackie and sonltd, Glassgow

Behbahaninia A, Mirbagheri SA, Khorasani N, Nouri J, Javid AH (2009) Heavy metal contamination of municipal effluent in soil and plants. J Food Agric Environ 7(3-4):851-856

Dominguez-Mariana E, Carrillo-Chvez A, Ortega A (2004) Wastewater reuse in valsequillo agricultural area, Mexico: environmental impact on groundwater. Water Air Soil Poll 155:251-267

Ensink HH, Mehmood T, Vand-der-Hoeck W, Raschid-Sally L, Amerasinghe FP (2004) A nation-wide assessment of wastewater use in Pakistan: an obscure activity or a vitally important one? Water Policy 6:197-206

Jiménez-Cisneros B (1995) Wastewater reuse to increase soil productivity. Water Sci Technol 32(12):173-180

Keraita BN, Drechsel P (2004) Agricultural use of untreated urban wastewater in Ghana. In: Scott CA, Faruqui NI, Raschid-Sally L (eds) Wastewater use in irrigated agriculture. CABI Publishing, Wallingford, UK

Kiziloglu FM, Turan M, Sahin U, Kuslu Y, Dursun A (2008) Effects of untreated and treated wastewater irrigation on some chemical properties of cauliflower (Brassica Olerecea L. var. botrytis) and red cabbage (Brassica Olerecea L. var. rubra) grown on calcareous soil in Turkey. Agr Water Manage 95:716-724

Lu GL, Han M, Li FS (2005) Monitoring of soil environment pollution and vegetable contamination by heavy metals in Tongzhou irrigation area of Beijing City. Environ MonitorChina 21(6):54-62

Mahasneh A, Al-Wir A, Salameh E, Batarseh L, Shatanawi M, Rimawi O, Judeh O, Khattari S, Oweis T (1989) Treated wastewater reuse in agriculture. part i. hussein medical center project, No. 12 Bulletin of Water Research and Study Center, University of Jordan

Mexico CAN (Commission National Del Agua) (2004) Water statistics. National Water Commission, Mexico City

Middlebrooks EJ (1982) Water reuse/ed (M). Ann Arbor Science, Ann Arbor

Mohammad Rusan MJ, Hinnawi S, Rousan L (2007) Long term effect of wastewater irrigation of forage crops on soil and plant quality parameters. Desalination 215:143-152

OMA (1990) Official methods of analysis, 15th edn. Association of Official Analytical Chemists, Arlington, Virginia, USA

Pendias AK, Pendias H (1992) Trace elements in soils and plants, 2nd edn. Boca Raton Arbor, London, pp 187-198

Pescod MB (1992) Wastewater treatment and use in agriculture. FAO. Irriga Drain Paper No. 47, Rome

Qadir M, Wichnels D, Raschid-Sally L, Singh Minhas P, Drechsel P, Bahri A, McCornick P (2007) Agricultural use of marginalquality water-opportunities and challenges. In: Molden D (ed) Water for food; water for life. A comprehensive assessment of water management in agriculture. Earthscan, 8-12 Camden High Street, London, pp 425-457

Rezvani Moghadam P, Mirzaei Najmabad M (2009) Effect of different sewage and water ratios on morphological traits, yield and yield components of four forage species. J Agron Res 7(1):63-75 (In Persian)

Singh G, Bahati M (2005) Growth of Dalbergia sissoo in desert regions of western India using municipal effluent and plant chemistry. Bioresour Technol 96:1019-1028

Standard Methods for the Examination of Water and Wastewater (1995) 19th edition. American Public Health Association/ American Water Works Association/Water Environmental Federation, Washington DC

Statistical Handbook (1996) Statistical handbook of Iran, Programming and Management Organization of Iran

Vafabakhsh K, Kharghany K (2000) Effects of treated municipal wastewater on quality and yield of cucumber and carrot. In: Agricultural resource recycling Symp, Isfahan. Khorasgan Azad University. Agricultural College, Iran (in Persian)

World Health Organization (WHO) (1980) Health aspects of treated sewage reuse(R). Report on WHO Seminar, Copenhagen

World Health Organization (WHO) (2006) Guidelines for the safe use of wastewater, excreta and greywater. Volume 2: Wastewater use in agriculture, Geneva

Yang HX (2002) Effects of irrigation with wastewater on the crops in Datong, Shanxi China. J Agron Environ Develop 4:18-19

Zavadil J (2009) The effect of municipal wastewater irrigation on the yield and quality of vegetables and crops. Soil Water Res 4(3):91-103

Zheljazkov VD, Nielsen NE (1996) Effect of heavy metals on peppermint and corn mint. Plant Soil 178:59-66 